\title{
TERORISME DAN URGENSI REVISI UU PEMBERANTASAN TINDAK PIDANA TERORISME?
}

\author{
Oleh: M. Jamil ${ }^{1}$
}

Semua agama di dunia pasti mengecap adanya terorisme, baik itu agama Kristen, Protestan, Hindu, Buddha, Konghuchu, lebih-lebih agama Islam. Bagi orang yang beriman, entah mengimani agama apa pun itu, pasti tidak mau agamanya dijangkiti orang atau sekelompok orang yang mempunyai paham atau penyebar paham terorisme, dengan kondisi yang demikian, sadar atau tidak, saat ini terorisme sudah di diskreditkan kepada agama tertentu, yakni agama Islam. Sebenarnya apa yang salah dengan agama Islam, bukankah Islam merupakan agama rahmatan lil alamin (rahmat untuk seluruh alam)?.

Pemberitaan media nasional maupun Internasional banyak mengarah pada pelabelan orang Islam atau agama Islam sebagai penyebar atau agama terorisme. Biar kita tidak terbawa arus oknum media massa yang tidak bertanggungjawab, alangkah baiknya kita mengetauhi seberti apa dan bagaimana itu terorisme. Mari kita simak penjelasan sederhana dibawah ini.

\section{Teroris, Terorisme dan Tidak Pidana Terorisme}

Menurut Kamus Besar Bahasa Indonesia (KBBI) menyebutkan bahwa teroris merupakan orang yang menggunakan kekerasan untuk menimbulkan rasa takut. Sedangkan terorisme adalah serangan-serangan terkoordinasi yang bertujuan membangkitkan perasaan teror terhadap sekelompok masyarakat. Berbeda dengan perang, aksi terorisme tidak tunduk pada tatacara peperangan

\footnotetext{
${ }^{1}$ Ketua Umum Pusat Studi Mahasiswa Pascasarjana (PUSMAJA) Mbojo-Yogyakarta Periode 2015-2017 | | Ketua II Bagian Eksternal Dewan Pimpinan Cabang Perhimpunan Mahasiswa Hukum Indonesia Daerah Istimewa Yogyakarta (DPC PERMAHI DIY) Periode 2012-2014 | Email: jamilncera@gmail.com | FB/Youtube/IG/Twitter: @MJAMILSH | Website: http://www.mjamil.my.id.
} 
seperti waktu pelaksanaan yang selalu tiba-tiba dan target korban jiwa yang acak serta seringkali merupakan warga sipil. (diex92.wordpress.com, 6/8/2016)

Pengertian Terorisme untuk pertama kali dibahas dalam European Convention on the Suppression of Terrorism (ECST) di Eropa tahun 1977 terjadi perluasan paradigma arti dari Crime against State menjadi Crime against Humanity. Crime against Humanity, meliputi tindak pidana yang dilakukan untuk menciptakan suatu keadaan yang mengakibatkan individu, golongan dan masyarakat umum ada dalam suasana yang mencekam. Terorisme dikategorikan sebagai suatu sebagai bagian serangan yang meluas atau sistematik, serangan itu ditujukan secara langsung terhadap penduduk sipil, lebih-lebih diarahkan pada jiwa-jiwa orang yang tidak bersalah (public by innocent) sebagaimana halnya terjadi di Bali. Seruan diperlukannya suatu perundang-undangan disambut prokontra mengingat polemik devinisi terorisme masih bersifat multi-interpretatif, umumnya lebih mengarah kepada polemik mengenai kepentingan negara atau state-interested. (Hery Firmansyah, "Upaya Penanggulangan Tindak Pidana Terorisme di Indonesia", Mimbar Hukum, Volume 23, Nomor 2, Juni, 2011 : 378379)

Di Indonesia memuncaknya isu terorisme yakni saat peristiwa pengeboman pada malam hari tanggal 12 Oktober 2002 yang terjadi di Bali. Adanya peristiwa tersebut menampar alam bawah sadar pemerintah, karena saat peristiwa bom Bali terjadi, belum ada aturan perundang-undangan yang mampu mengakomodir dengan jelas untuk menangani peristiwa terorisme tersebut. Oleh karena terjadi peristiwa yang genting, maka pada tahun 2002 Presiden saat itu Megawati Soekarno Putri pada pada tanggal 18 Oktober 2002 menerbitkan Peraturan Pemerintah Pengganti Undang-Undang Republik Indonesia Nomor 1 Tahun 2002 Tentang Pemberantasan Tindak Pidana Terorisme (Perppu Terorisme). Selang beberapa bulan, tepatnya pada tanggal 4 April 2003 Perppu Terorisme diresmikan menjadi undang-undang, sehingga menjadi UndangUndang Republik Indonesia Nomor 15 Tahun 2003 Tentang Penetapan Peraturan Pemerintah Pengganti Undang-Undang Nomor 1 Tahun 2002 Tentang Pemberantasan Tindak Pidana Terorisme (UU Terorisme). 
Hadirnya Perppu tentang Terorisme memberi gambaran pengertian tentang tindak pidana terorisme. Pada Pasal 1 Ayat 1 Perppu tentang Terorisme memberi pengertian bahwa Tindak pidana terorisme adalah segala perbuatan yang memenuhi unsur-unsur tindak pidana sesuai dengan ketentuan dalam Peraturan Pemerintah Pengganti Undang-undang ini. Makna segala perbuatan dalam Pasal 1 Ayat 1 diatas yakni segala perbuatan setiap orang dan segala perbuatan korporasi. Pasal 1 Ayat 2 Perppu Terorisme memberi pengertian bahwa setiap orang adalah orang perseorangan, kelompok orang baik sipil, militer, maupun polisi yang bertanggung jawab secara individual, atau korporasi. Sedangkan Pasal 1 Ayat 3 Perppu Terorisme memberi pengertian bahwa korporasi adalah kumpulan orang dan/atau kekayaan yang terorganisasi baik merupakan badan hukum maupun bukan badan hukum.

Banyak negara telah memuji keseriusan Indonesia dalam menangani kasus bom Bali. Hanya dalam tempo kurang dari tiga bulan, hampir semua pelaku terorisme di Bali tertangkap. Bandingkan dengan Amerika Serikat yang membutuhkan waktu sampai berbulan-bulan untuk menangkap para tersangka teroris yang menghancurkan World Trade Center (WTC). (A. M. Hendropriyono, 2009: 269)

Selain menerbitkan UU Terorisme, pemerintah juga melakukan upaya pembentukan UU lain sebagai pendukung upaya pemberantasan tindak pidana terorisme di Indonesia, UU yang dimaksud salahsatu diantaranya adalah menerbitkan Undang-Undang Republik Indonesia Nomor 9 Tahun 2013 Tentang Pencegahan dan Pemberantasan Tindak Pidana Pendanaan Terorisme. Pada pasal 1 Ayat 1 UU Nomor 9 Tahun 2013 menerangkan pendanaan terorisme adalah segala perbuatan dalam rangka menyediakan, mengumpulkan, memberikan, atau meminjamkan dana, baik langsung maupun tidak langsung, dengan maksud untuk digunakan dan/atau yang diketahui akan digunakan untuk melakukan kegiatan terorisme, organisasi teroris, atau teroris.

\section{Akibat Hukum Pelaku Tindak Pidana Terorisme}


Negara Indonesia adalah negara hukum, begitu bunyi Pasal 1 Ayat (3) amandemen ketiga Undang-Undang Dasar Negara Republik Indonesia Tahun 1945 (UUD 1945). Karena Negara Kesatuan Republik Indonesia (NKRI) menganut Negara hukum, maka dalam suatu negara hukum semua orang harus diperlakukan sama dihadapan hukum (equality before the law). Oleh karenanya, setiap orang yang melakukan perbuatan melawan hukum, termasuk pelaku tindak pidana terorisme, maka akan menerima konsekwensi hukum atas apa yang ia perbuat.

Pada BAB III Perppu Terorisme, menjelaskan akibat hukum pelaku tindak pidana terorisme. Pada Pasal 6 menerangkan bahwa setiap orang yang dengan sengaja menggunakan kekerasan atau ancaman kekerasan menimbulkan suasana teror atau rasa takut terhadap orang secara meluas atau menimbulkan korban yang bersifat massal, dengan cara merampas kemerdekaan atau hilangnya nyawa dan harta benda orang lain, atau mengakibatkan kerusakan atau kehancuran terhadap obyek-obyek vital yang strategis atau lingkungan hidup atau fasilitas publik atau fasilitas internasional, dipidana dengan pidana mati atau penjara seumur hidup atau pidana penjara paling singkat 4 (empat) tahun dan paling lama 20 (dua puluh) tahun. Sedangkan Pasal 7 menerangkan bahwa setiap orang yang dengan sengaja menggunakan kekerasan atau ancaman kekerasan bermaksud untuk menimbulkan suasana teror atau rasa takut terhadap orang secara meluas atau menimbulkan korban yang bersifat massal dengan cara merampas kemerdekaan atau hilangnya nyawa atau harta benda orang lain, atau untuk menimbulkan kerusakan atau kehancuran terhadap obyek-obyek vital yang strategis, atau lingkungan hidup, atau fasilitas publik, atau fasilitas internasional, dipidana dengan pidana penjara paling lama seumur hidup.

\section{Peran Pemerintah dan Stake Holder dalam Pemberantasan Terorisme}

Terorisme memiliki berbagai karakteristik, salah satu karakteristik terorisme adalah semangat radikalisme agama. Untuk menangkal dan meminimalisir terjadinya terorisme, pemerintah harus lebih proaktif sebagai aktor utama yang harus membendung aksi brutal terorisme. Upaya yang perlu 
dilakukan, seperti melakukan kerja sama dengan sejumlah organisasi masyarakat, kepemudaan, mahasiswa dan ulama. Ini semua dilakukan sebagai upaya dini dan penyadaran akan bahaya terorisme yang kian mengakar didalam masyarakat. Kerja sama yang dapat dilakukan misalnya dalam bentuk pengadaan seminar, dialog, dan sosialisasi. Dalam keadaan apapun, pemerintah tidak boleh menutup mata dan telinga dalam urusan kejahatan atas kemanusiaan ini, lebih-lebih ditingkat lokal. Sebab, kejahatan terorisme yang berskala nasional dimulai dari kurangnya penanganan ditingkat lokal. Pembiaran seperti ini tidak boleh lagi dilakukan, wajah pemerintah yang pasif harus dirubah demi kebaikan bersama. (Zulchijjah, "Penelusuran dan Penanganan Terorisme di Aras Lokal", www.kahaba.net, 5/8/2016)

\section{Urgensi Revisi UU Pemberantasan Tindak Pidana Terorisme?}

Sudah kuranglebih 13 tahun pemberlakuan UU Terorisme, yang harus kita telusuri bersama, 13 tahun berlakunya UU Terorisme, apakah sejauh ini sudah mampu mengakomodir semua persoalan yang berkaitan dengan terorisme. Seiring berkembangnya jaman, berkembang juga persoalan-persoalan hukum yang terjadi di negeri ini, sehingga dalam bebeapa tahun terakhir ini banyak juga isu yang muncul dipermukaan yang mengarah pada perlunya revisi UU Terorisme. Mungkin sudah terlalu usang, sehingga perlu adanya penyegaran agar UU Terorisme mampu mengakomodir dan meminimalisir segala arus lalulintas persoalan terorisme. Isu-isu yang berkembang tidak hanya terjadi pada masyarakat yang tidak lagi kurang puas dalam melihat penanganan tindak pidana terorisme yang diakomodir oleh UU Terorisme tersebut, selain itu, saat ini juga kencang terjadi isu-isu revisi UU Terorisme yang dilakukan atau sedang digaungkan oleh pemerintah.

Terkait isu revisi UU Terorisme, diwartakan tempo.co 22-01-2016, seperti halnya yang dilakukan oleh Menteri Hukum dan Hak Asasi Manusia Yasonna Laoly mengatakan ada sejumlah poin yang menjadi usulan pemerintah dalam revisi, diantaranya, poin pertama, Perluasan masa penahanan selama penyelidikan atau penyidikan. Point kedua, pencabutan status kewarganegaraan 
atau paspor dari warga negara Indonesia yang melakukan tindakan yang mengancam keselamatan negara, baik di Indonesia maupun di luar negeri. Point ketiga, izin validitas alat bukti terorisme. (www.tempo.co, 5/8/2016)

Yang tidak kalah seksi dalam memperdebatkan isi revisi UU Terorisme adalah terkait adanya isi Rancangan Undang Undang (RUU) Terorisme yang telah digodok pemerintah, yang didalamnya salahsatu diantaranya tentang pelibatan Tentara Negara Indonesia (TNI) dalam memberantas terorisme.

Menurut Ketua Komisi III Dewan Perwakilan Rakyat Republik Indonesia (DPR RI), Bambang Soesatyo, di Gedung DPR, Senin, 25 Juli 2016, mengatakan bahwasannya mendorong Tentara Nasional Indonesia (TNI) dalam menangani teroris sebagai cara berpikir mundur dan kontraprodukif dengan agenda reformasi. Tidak ada urgensi mendesak dengan memperluas tugas pokok dan fungsi TNI melalui Revisi Undang-Undang (RUU) Nomor 15 Tahun 2003 tentang Pemberantasan Tindak Pidana Terorisme. RUU tersebut tak boleh kebablasan dengan memanfaatkan TNI oleh negara atas kekuatan dan kemampuan tentara. Pelibatan TNI mesti merujuk pada Undang-Undang Nomor 34 Tahun 2004 tentang TNI dan Undang-Undang Nomor 3 Tahun 2002 tentang Pertahanan Negara. Masalahnya, cakupan kebijakan dan strategi nasional dalam penanggulangan tindak pidana terorisme sangatlah luas. Ada langkah pencegahan, perlindungan, deradikalisasi, penindakan, penyiapan kesiapsiagaan nasional dan kerja sama internasional. Dengan melibatkan TNI dalam tugas memerangi tindak pidana terorisme akan berdampak pada konsekuensi logis yang amat luas dan prinsipil. Semua konsekuensi tersebut mesti dipatuhi dan dijalankan. Penanganan tindak pidana terorisme masuk dalam kerangka penegakan hukum. Oleh karena itu, menempatkan dan memberi wewenang TNI sebagaimana diatur dalam Pasal 43A ayat (3) dan 43B ayat (1) dalam draf RUU Terorisme menjadi tidak masuk akal. Bahkan tidak sejalan dengan agenda reformasi dalam mewujudkan keamanan dan ketertiban umum dalam Negeri. (www.hukumonline.com, $5 / 8 / 2016)$

Tidak hanya di tataran nasional, tingkat lokal pun sedang gencar membahas isu Revisi UU Terorisme, salahsatu daerah yang sedang gencar 
membahas terkait Revisi UU Terorisme adalah Kabupaten Bima dan dan Kota Bima. Bima gencar dalam ikutserta dalam mengawal Revisi UU Terorisme bukan tanpa alasan. Penyebabnya adalah team Panja DPR RI menjadikan Bima sebagai sample RUU Terorisme. Berbagai macam tangggapan yang dilontarkan oleh para tokoh lokal asal Bima maupun tokoh Nasional asal Bima, yang pada intinya merasa gusam atau tidak menerima Bima dijadikan salahsatu sample pembentukan RUU Terorisme. Banyak tokoh nasional yang lahir dari rahim lokal daerah Bima, beberapa diantaranya Prof. Afan Gaffar (tokoh dari timur yang disegani) yang merupakan salahsatu penggagas Otonomi Daerah dan juga guru besarnya para guru besar (salahsatu muridnya yang saat ini menjadi tokoh nasional adalah Dr. Ni'matul Huda, S.H., M.Hum.). Selain itu, tokoh nasional asal Bima ada Dr. Hamdan Zoelva, S.H., M.H. (mantan Ketua Mahkamah Konstitusi Republik Indonesia - MK RI), Dr. Anwar Usman, S.H., M.H. (Wakil Ketua MK), Prof. Farouk Muhammad, S.H. (Wakil Ketua Dewan Perwakilan Daerah Republik Indonesia - DPD RI), dan masih banyak tokoh nasional lainnya. Dalam dunia ulama dikenal tokoh Bima dengan nama Syaikh Abdul Ghani Al-Bimawi. Dengan bertebarnya tokoh nasional asla Bima di Nusantara ini, sangat tidak elok bila Bima dijadikan salahsatu sample pembentukan RUU Terorisme.

Sebagai orang Bima, penulis juga merasa tergelitik mendengar isu Bima dijadikan sebagai salahsatu sample pembentukan RUU Terorisme. Walau secara umum orang Bima berwatak agak keras, terkadang sering terjadi perkelahian antar Desa, bukan berarti membenarkan Bima sebagai sarang teroris, tidak sedikit juga terjadi salah tangkap yang terjadi di Bima beberapa waktu lalu, dikira teroris padahal bukan.

Secara umum Penulis mendukung rencana revisi UU Terorisme, karena sudah 13 tahun pemberlakuannya masih banyak juga pasal-pasal yang tidak lagi mampu mengakomodir situasi dan kondisi saat ini, sehingga perlu adanya penyegaran (revisi) agar bisa menjadi gawang terdepan untuk pemberantasan tindak pidana terorisme di Indonesia. Selain itu, pemerintah juga harus jeli menjadikan suatu daerah sebagai sample dalam pembentukan peraturan perundang-undangan (lebih-lebih RUU Terorisme), jangan sampai seperti dalam 
“Terorisme dan Urgensi Revisi UU Pemberantasan Tindak Pidana Terorisme?"

istilah penangkapan (salah tangkap), maka dalam penentuan daerah sebagai salahsatu sample pembentukan undang-undang pun jangan sampai salah penentuan.

Pada prinsipnya semua agama di dunia ini, oknumnya bisa berpotensi sebagai terorisme, baik itu agama Kristen, Protestan, Hindu, Buddha, Konghuchu, Islam maupun Agama dan kepercayaan lainnya. Oleh karenanya, pelabelan secara massal pada agama tertentu sebagai sarang terorisme harus kita hindari bersama, apalagi di Indonesia terbingkai dalam Bhineka Tunggal Ika (yang walau pun berbeda suku, ras, agama, dan kepercayaan dalam pribadi masing-masing, namun tetap satu tujuan) yakni tujuan sama-sama meyakini Indonesia sebagai satu tumpah darah dan sama-sama bercita-cita menjadikan bangsa Indonesia menjadi bangsa yang besar serta disegani oleh bangsa-bangsa lain.

Wallahu A'lam Bishawab.

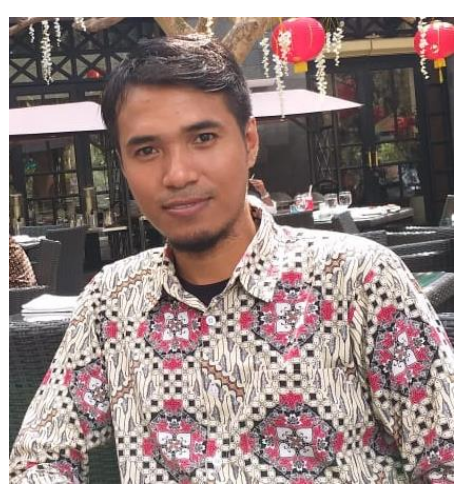

Penulis: M. Jamil, S.H.

Ketua Umum Pusat Studi Mahasiswa Pascasarjana (PUSMAJA) Mbojo-Yogyakarta Periode 2015-2017 | Ketua II Bagian Eksternal Dewan Pimpinan Cabang Perhimpunan Mahasiswa Hukum Indonesia Daerah Istimewa Yogyakarta (DPC PERMAHI DIY) Periode 2012-2014

\section{Ful Sumber Tulisan:}

M. Jamil, "Terorisme dan Urgensi Revisi UU Pemberantasan Tindak Pidana Terorisme?", Majalah NUSANTARA IKPMDI-Yogyakarta, diterbitkan melalui Dinas Pendidikan Pemuda dan Olahraga (Disdikpora) Daerah Istimewa Yogyakarta, edisi Mei-Juni 2016, lihat Halaman 22-24. 